\title{
Contribution of KhRILLH to the Study of Modern State of the Khakass Ethnos
}

\author{
Valentina N. Tuguzhekova* \\ Khakass Research Institute of Language, \\ Literature and History \\ 23 Shchetinkin Str., Abakan \\ Republic of Khakassia, 655017, Russia
}

Received 23.09.2014, received in revised form 14.10.2014, accepted 02.11.2014

In the paper the author observes the role of the Institute in the study of processes taking place among indigenous ethnos of the Republic of Khakassia at the turn of the 20-th-the beginning of the 21-st century is under consideration. In cooperation with institutes RAS and SB RAS some complex researches were held in the region. The author determined the problems of the Khakass people, one important of which is linguistic assimilation. The results of scientists' joint work are published in monographs and books.

Keywords: Khakassia, indigenous ethnoses of Siberia, science institute.

Research area: History.

The end of the $20^{\text {th }}$ century was tragic for Russia, for the entire multinational people. The breakup of the USSR and economic reforms affected all sides of population's life activity. On the huge territory of the former Soviet Union there were changes which had social-economic and political events of prime importance. They influenced not only on Russia but also on the whole world community.

It is worthy of note that the beginning of liberal reforms concurred with the formation of Khakassia as an independent subject of the Russian Federation (3 June 1991).

In December 1995 Council of Ministers of the Republic of Khakassia adopted "Program of revival and spiritual development of the Khakass ethnos for 1996-2000”. KhRILLH took an active part in implementation of this program as at that moment state processes of the Khakass ethnos had been investigated poorly [Krivonogov, 1997, p.8]. In V. P. Krivonogov's monograph “The Khakass. Ethnic processes in the second half of the $20^{\text {th }}$ century" the author studied ethnic processes which had been taking place during the Soviet period and their analysis was finished with the results of the All-Russian population census of 1989 [Krivonogov, 1997, p. 144]. Regarding ethnic self-consciousness of the Khakass people V. P. Krivonogov noted that they "have not got a notion of kin solidarity, kin mutual help... Memory preservation about belonging to one or another kin as a part of population is for nothing

(c) Siberian Federal University. All rights reserved

* Corresponding author E-mail address: khaknauka@yandex.ru 
in modern life. Data about a kin system is not conveyed to next generations. In the 1990s national organizations and clerisy's attempts to revivify kin notions appeared. But it is early to judge what will form from these attempts" [Krivonogov, 1997, p. 66]. Today in these processes we note positive tendencies. In 1997 there was favorable foundation of Council of Elders of the Khakass people. Today kin meetings and festivals are held regularly in all regions of Khakassia. But at that time in the 1990s all these meetings were only being revived. Processes of ethnic revival of Russian people set many questions and tasks. The most important one was to prevent ethnic conflicts, preserve social-cultural unity of territories and the state in general.

Our institute had a task of studying the processes which had been taking place among the indigenous ethnos under conditions of global changes, modernization of society and social transformations. Due to absence of our own specialists at that period, we called for researchers from academic science institutes in Novosibirsk and Moscow. In cooperation with Institute of Philosophy and Law SB RAS and Institute of Ethnology and Anthropology RAS we held researches on the following projects and branches:

International project "Ethno-social processes in Central Asia: Eurasian perspective. (International comparative research)" - Institute of Philosophy and Law SB RAS. "Developmental problem of the Khakass people under circumstances of Russian reforms";

Project "Family - Marriage - Parents Children";

Regional project "Women of Tuva and Khakassia during the period of Russian reforms";

Social stratification and interethnic directives of main ethnic groups of Tuva and Khakassia (a comparative analysis), Moscow (Z. V. Anaiban);
Institute of Ethnology and Anthropology RAS. Project "Ethno-regional models of population's adaptation under circumstances of transforming society" (post-Soviet experience), and etc.

Within the framework of the project "Ethnoregional models of population's adaptation under circumstances of transforming society" in May 2003 in Abakan 600 citizens were surveyed, including 300 Khakass and 300 Russians. Besides, the poll was carried out in Shirinsky region. According to the results 4 informationanalytical bulletins of authors Z. V. Anaiban, L. V. Ostapenko, I. L. Subbotina and a monograph "Post-Soviet Khakassia" were published.

According to these results and a range of other social researches a line of books was issued. They were edited in cooperation with SB RAS and RAS:

1. Kostiuk V. G., Popkov Iu. V., Tuguzhekova V. N. Development problem of the Khakass people under circumstances of Russian reforms of the 1990s (sociological evaluation). Abakan, 2000. 72 p.

2. Kostiuk V. G., Popkov Iu. V., Tuguzhekova V. N. Ethnoses of Siberia under circumstances of modern reforms (sociological evaluation). Novosibirsk. 2003. $126 \mathrm{p}$.

3. Anaiban Z. V. Women of Tuva and Khakassia during the period of Russian reforms. Moscow. 2005. 243 p.

4. Post-Soviet Khakassia. Moscow. 2005. $482 \mathrm{p}$.

5. Goncharova G. S., Savel'ev L. Ia. Familymarriage relationships of Siberian peoples. Novosibirsk, 2004. 286 p.

6. Logacheva A. S. Modern Khakassia: ethno-social processes. Abakan, 2006. $115 \mathrm{p}$.

Besides, researchers of the Institute conducted researches on social-economic 
situation of the Republic of Khakassia, problems of international relations, family problems, ethnic self-consciousness and etc. Monographs of V. K. Shulbaiev "Khakassia in the 1990s of the $20^{\text {th }}$ century: problems of social-economic development" (2004); V. N. Tuguzhekova, O. M. Karachakova "International relations in Khakassia at the end of the $20^{\text {th }}$ century (19801990)" (2005); V. N. Tuguzhekova "The Khakass ethnos at the turn of the century" (2008); A. S. Logacheva "Ethnic self-consciousness (based on Khakass ethnos)" (2009); V. P. Krivonogov "The Khakass in the early $21^{\text {st }}$ century: modern ethnic processes" (2011); I. N. Troshkina "Dynamics of family institution: social-philosophical aspect (based on material of the Republic of Khakassia)" (2012), and etc., were published (see further Reports on scientific and scientific-organizational activity of KhRILLH for 2006-2012).

In 2009 for these and other researches in the Khakass ethnos the Institute was awarded with an order "For Good Deeds" by republican Council of Elders.

The results of sociological investigations showed problems which had appeared in the course of reforms. It was difficult for the indigenous ethnos to adapt to changing conditions. But as early as the beginning of 2000 the population of Khakassia started to adapt to new conditions.

Since the middle of 1990 in the Republic of Khakassia a normative-legal basis started to be created. In it aims of preservation and development of the Khakass ethnos were reflected in one or another form. Great attention was paid to Governmental program on preservation and development of peoples' languages in the Republic of Khakassia. It was implemented on the basis of a rule "On peoples' languages of the Republic of Khakassia" (1992).

Researches on the Khakass language show that in spite of actions in the language preservation in recent decades there has been an accelerating process of linguistic assimilation. So, according to the results of the All-Russian population census (2010), only $38.9 \%$ Khakass people know the Khakass language. In absolute figures it is 38.897 of 63.643 Khakass people living in the Republic of Khakassia (see further Results of the All-Russian population census of 2010).

The ethnographer V. P. Krivonogov studied the process which had been taking place in the language sphere. Here are some tendencies [Krivonogov, 2011, pp. 70-74]:

The Khakass language includes four dialects: Kachin, Sagay, Kyzylian and Shorian. The Koibals do not have their own dialect. Their speech peculiarities are visible at a pronunciation level which has an intermediate position between the Sagay and Kachin dialects. In the past the Beltirian dialect existed. It was merging gradually with Sagay. And now it appears as an accent included into the latter.

The degree of competence of different subethnoses in the native language differs considerably even if to bear in mind not a literary language but only a dialect. That is connected first of all with different degree of merging while settling. As the result of a sociological research, the Khakass language was proclaimed as native for $62.7 \%$ of the Sagays, $64.3 \%$ - the Koibals, $4.7 \%$ - the Shors, $47.6 \%$ - the Kyzyls and $40.0 \%$ - the Kachins. 30 years ago the Khakass language was called native most frequently by the Sagays ans Shors, in a lesser degree by the Koibals, then the Kachins followed and at the end - the Kyzyls. Then some regrouping has occurred. The Sagays and Koibals became leaders. The Shors have lower rates. After them there are the Kyzyls and at the end - the Kachins. According to rates of the main spoken language the difference between subethnoses is like this: $44.0 \%$ of the Sagays, $37.4 \%$ of the Koibals, $31.5 \%$ of the Shors, $12.1 \%$ of the Kachins and $9.2 \%$ of the Kyzyls consider the 
Khakass language (or two languages) as their main spoken language. According to these data, the Sagays are at the first place and situation of the Kachins is better a little than of the Kyzyls. As for the third language, degree of knowledge of the Khakass language of subethnoses is as follows: $54.5 \%$ of the Koibals, $54.4 \%$ of the Sagays, $45.0 \%$ of the Shors, $24.6 \%$ of the Kyzyls and $23.4 \%$ of the Kachins speak the Khakass language fluently. The Sagays and Koibals have almost similar rates. They are leaders. The Shors are behind them. The Kachins and Kyzyls are outsiders. The share of those who do not understand the Khakass language is $26.8 \%$ of the Kachins and $31.5 \%$ of the Kyzyls. So, in general, the Kachins' situation is a little bit better. Summing up all three language rates, it is possible to distribute subethnoses this way: the leaders are the Sagays and Koibals. The Shors have lower rates. The Kachins and Kyzyls are in the worst situation.

Not all Khakass people, who know the Khakass language, speak a dialect of their group. Living outside the subethnic territory of their group some representatives of subethnoses acquire different dialects. The dialect mainly corresponds to subethnic origin. $77.5 \%$ of the Sagays (elder than 7) speak the Sagay dialect. $6.1 \%$ speak different dialects. $16.4 \%$ do not know any dialect. The $54.9 \%, 51.3 \%, 58.8 \%$ and $52.3 \%$ of the Kachins, Kyzyls, Shors and Koibals correspondingly speak their dialect.

Since the Sagays are $71.7 \%$ of the whole population of the Khakass, they make up $76.8 \%$ of those who speak the Khakass language fluently. And the representatives of other subethnic groups, especially the Kachins and Kyzyls, speak the Khakass language worse. Among those who speak this language fluently the Kachins make up $10.4 \%$, the Kyzyls - only $2.1 \%$. It is much less than the share of these ethnoses in the whole population.
In general, in the number of the Khakass people elder than 7 years old there are $52.6 \%$ of native Sagay speakers, $13.6 \%$ - of Kachin, $1.7 \%$ - of mixed Kachin-Sagay, $2.2 \%$ - of Kyzylian, $4.4 \%$ - of Shorian, $1.9 \%$ - of the Koibal dialect. Another $3.0 \%$ speak more than one dialect. But $20.6 \%$ do not speak any dialect. They are those who do not speak Khakass at all or speak it poorly.

Nevertheless in the sphere of linguistic situation there are also positive tendencies because in recent years an interest to the native culture has increased.

According to the recent data, $24 \%$ of adult population read fiction in their native language, $79 \%$ of senior high school students in a village and $50 \%$ in a town listen to programs in the Khakass language. A questionnaire survey of parents of Khakass nationality showed that $95 \%$ of parents considered the study of the Khakass language by their children necessary [Current archive of KhRILLH, p.22].

Therefore an important fact of the national language's preservation and development is the Khakass language teaching at school. At present $72 \%$ of Khakass children study the Khakass native language at 121 schools.

For the recent four years 56 items of training literature for the study of the Khakass language, Khakass literature and subjects with ethno-cultural content have been issued in the Republic.

Our institute conducts fundamental and applied researches on the study of the Khakass language. For the recent years the department of the Khakass language has issued a range of dictionaries:"Khakass-Russiandictionary"(2006) and "Russian-Khakass dictionary of linguistic terms" (2012), edited by O. V. Subrakova; Z. Ie. Kaskarakova prepared "Dictionary of homonyms of the Khakass language" (2009) and "RussianKhakass dictionary of social and political terms" 
(2012); the work on a definition dictionary is almost completed. Just for the recent 5 years the department of the Khakass language has prepared 15 publications on the study and development of the Khakass language.

One of the most severe problems of the Khakass people is demographic processes which have influenced negatively on number of the Khakass people. Resume of the All-Russian population census of 2010 showed reduction of the absolute Khakass population number by $3.52 \%$.

Reduction of the Khakass population took place in Khakassia too as compared with 2002.
According to the results of population census in 1989 there were 62,859 Khakass people, in $2002-65,421$ people, in 2010 - 63,643 people. This situation should be investigated. Khakass youth is eager to be educated out of the Republic but after graduating from universities only few of them come back.

One of the main challenges facing scientific society of the Republic is formation of the Khakass population's stable interest to the study of their native language, literature, folklore, history, culture, understanding of necessity of their preservation and development, upbringing of patriots of their own motherland.

Dynamics of the Khakass population number (1897-2010)

\begin{tabular}{|l|c|c|c|c|c|c|c|c|}
\hline & 1897 & 1926 & 1939 & 1959 & 1970 & 1979 & 1989 & 2010 \\
\hline Thousands of people & 42,7 & 45,6 & 52,8 & 56,8 & 66,7 & 70,8 & 80,3 & 75622 \\
\hline Annual increase (in \%) & - & $+0,3$ & $+1,1$ & $+0,3$ & $+1,5$ & $+0,6$ & $+1,3$ & $-3,52$ \\
\hline
\end{tabular}

\section{References}

1. Krivonogov, V. P. The Khakass. Ethnic processes during the second half of the $20^{\text {th }}$ century. Abakan, 1997. p. 8.

2. Q.v.: Reports on scientific and scientific-organizational activity of KhRILLH for 2006-2012. Abakan, 2007-2013.

3. Results of the All-Russian population census of 2010. In 11 volumes. Volume 4, book 1 . Moscow, 2012, p. 213.

4. Krivonogov V. P. The Khakass in the beginning of the 21 st century: modern ethnic problems. Abakan, 2011, P. 70-74.

5. Current archive of KhRILLH. Linguistic situation in the Republic of Khakassia (date of reference: 1.04.2012). P. 22. 


\section{Вклад ХакНИИЯЛИ \\ в изучение современного состояния \\ хакасского этноса}

\section{В.Н. Тугужекова}

Хакасский научно-исследовательский институт языка, литературы и истории Россия, 655017, Республика Хакасия Абакан, ул. Щетинкина, 23

В статье рассматривается роль института в изучении прочессов, происходящих среди коренных этносов Республики Хакасия на рубеже XX - начала ХХІ вв. В сотрудничестве с институтами РАНи СО РАН в регионе были проведены комплексные исследования и определень проблемы хакасов, одной из самых важных является языковая ассимиляция. По результатам совместной работы ученых опубликованы монографии и книги.

Ключевые слова: Хакасия, коренные этносы Сибири, научно-исследовательский институт.

Научная спеииальность: 07.00.00 - исторические науки. 